$09 ; 14 ; 15$

\title{
Анализатор спектра флуоресценции на основе оптоволоконного $Y$-циркулятора
}

\author{
() Э.К. Алгазинов, В.А. Шульгин
}

Воронежский государственный университет, Воронеж, Россия

๑E-mail: shulgin@cs.vsu.ru

Поступило в Редакцию 5 февраля 2018 г.

Рассмотрен способ зондового анализа на основе оптоволоконной составной конструкции $Y$-циркулятора для реализации аппаратных средств лазерной флуоресцентной диагностики. В основе предложенного принципа построения анализатора лежит пространственное разделение направленных оптических пучков возбуждающего и флуоресцентного излучений. Проведен анализ условий применения $Y$-циркулятора в качестве пассивного оптоволоконного коммутатора. Выполнены экспериментальные исследования потерь коммутируемых излучений. Представлен пример использования анализатора для флуоресцентной диагностики биологических сред.

DOI: $10.21883 /$ PJTF.2018.14.46344.17238

В настоящее время лазерные технологии активно используются для решения широкого класса задач, в том числе и в различных областях биологии и медицины. Проводимое с их помощью комплексное изучение характеристик поглощения, светорассеяния, люминесценции в сочетании с использованием математических моделей сложноструктурированных биологических сред [1,2] позволяет быстро интактно обнаруживать физиологические и морфологические изменения. Во многих приложениях актуальна задача создания системы диагностики непосредственно in vivo. Повышенный интерес в исследованиях in vivo проявляется к флуоресцентному спектральному анализу (ФСА), так как возбуждение клеточных структур и флуоресцентный отклик относятся к видимому и ближнему инфракрасному диапазонам спектра, в которых минимально нарушение жизнедеятельности биообъекта [3]. В задачах, не требующих получения изображений с высоким разрешением, используются методы ФСА с помощью оптоволоконных систем, которые обеспечивают передачу излучения между объектом, лазерным источником и анализатором. Известны два варианта их построения: с разделением 


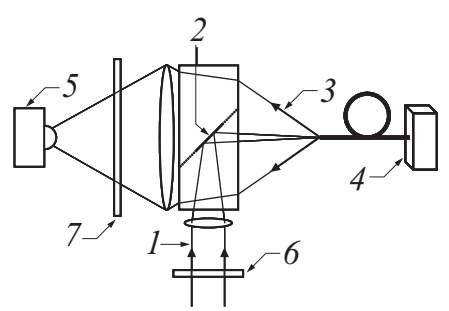

$b$

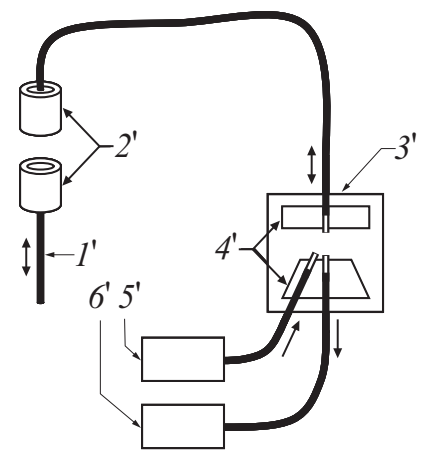

Рис. 1. Направляющая система пространственного разделения оптических пучков возбуждающего лазерного излучения и флуоресцентного отклика $(a)$ и схема оптоволоконного коммутатора оптических пучков возбуждающего лазерного излучения и флуоресцентного отклика $(b)$. Пояснения приведены в тексте.

оптических волокон по функциональному признаку на излучающие и приемные $[4,5]$ и с одним волокном [6], передающим излучение лазерного источника в область контакта с объектом, собирающим флуоресцентный отклик и направляющим его с помощью дихроичного зеркала на вход спектрометра. В последнем случае реализуется принцип „невзаимной коммутации“ [7], базирующийся на спектральной селекции.

Целесообразным подходом, по нашему мнению, является использование схем ФСА, в которых спектральная селекция заменена на селекцию (невзаимную коммутацию) встречных пространственных пучков возбуждающего излучения и флуоресцентного отклика $[8,9]$. Задачей настоящей работы являются анализ и исследование инвариантных к длине волны возбуждающего источника контактных средств ФСА с использованием оптоволоконного зонда, представляющего собой элемент трехпортового $Y$-циркулятора.

В рамках предлагаемого подхода в реализованной системе ФСА, показанной на рис. $1, a$, отсутствуют частотно-зависимые элементы разделения излучения. Ширина диапазона длин волн здесь ограничена только параметрами линзовой и призменной оптики. Выбор частотного диапазона исследований определяется источником лазерного излуче-

4* Письма в ЖТФ, 2018, том 44, вып. 14 
ния 1 и соответствующими фильтрами 6, 7. Минимизация потерь флуоресцентного излучения объекта 4 в схеме на рис. $1, a$ достигается за счет разницы между апертурным углом пучка 3 оптического волновода и пространственным углом вводимого в волновод лазерного пучка 1 . Апертура металлического зеркального покрытия 2 минимальна, что позволяет лишь незначительной части энергии пучка флуоресценции 3 , направляемого в спектрометр 5 , отразиться от зеркальной поверхности 2.

Дальнейшее развитие предлагаемого подхода реализовано в системе, представленной на рис. $1, b$. Здесь используются возможности волоконной оптики, позволяющие создать схему невзаимной коммутации оптических пучков малой апертуры по принципу $Y$-циркулятора. Преимущество данной системы состоит в том, что она не содержит делительных зеркал, линзовой оптики, элементов оптической юстировки. Предложенный принцип коммутации оптических пучков решает задачу их разделения независимо от спектрального и модового состава излучения, а также поляризации. В рассматриваемом $Y$-разветвителе невзаимность обусловлена топологией коммутации оптических пучков. Излучение торца оптического волновода (первый порт разветвителя), сопряженного с лазерным источником $5^{\prime}$, возбуждающего флуоресценцию, направляется в торец волновода (второй порт разветвителя) под некоторым углом, задаваемым направляющей системой $3^{\prime}$ и $4^{\prime}$. Волновод второго порта оптическим разъемом $2^{\prime}$ связан с „зондом“ ${ }^{\prime \prime}$ необходимой длины, выходной торец которого контактирует с исследуемым объектом. Диффузное излучение флуоресцентного отклика поступает во второй порт в пределах апертурного угла волновода, излучается из противоположного торца в осевом направлении и вводится в волновод (третий порт разветвителя), ось которого является продолжением оси волновода „зонда“. Далее излучение направляется в спектрометр $6^{\prime}$. При этом внешнее освещение не будет добавлено к сигналу флуоресценции, что важно при практическом использовании устройства.

При обосновании схемы, показанной на рис. $1, b$, проводились выбор параметров оптических волокон и анализ влияния топологии с точки зрения минимизации потерь мощности при передаче излучения флуоресценции объекта на вход спектрометра и преобразования спекловой структуры излучения волновода, а также возможностей применения анализатора для безопасной зондовой регистрации спектров флуоресценции биологических объектов.

Письма в ЖТФ, 2018, том 44, вып. 14 
Выбор используемого типа волокон и их параметров для зонда при сборке $Y$-разветвителя осуществлялся исходя из условия минимизации потерь мощности при коммутации направляемых оптических пучков в торцы сопряженных волноводов, имеющих ограниченную апертуру сечения захвата излучения. При этом отношение диаметра волновода к диаметру волокна желательно обеспечить максимально близким к единице [9]. Использованные нами кварц-полимерные многомодовые волокна характеризуются стандартным рядом диаметров волновода $d=200,400 \mu \mathrm{m}$ и т. Д. и отражающей полимерной оболочки толщиной $h \sim 10-20 \mu \mathrm{m}$. Диаметр волновода близок в них к диаметру волокна, что позволяет минимизировать потери при коммутации оптических пучков составного $Y$-разветвителя [9], выполняющего в данном случае функцию трехпортового циркулятора. Остальные типы волокон общего применения по этому критерию имеют худшие характеристики.

Положительным эффектом при использовании косого ввода лучей в волновод является возможность подавления спеклового шума в области низких пространственных частот. Известно, что распределение поля кварц-полимерного многомодового волновода в дальней зоне торца в пределах апертурного угла аппроксимируется функцией Гаусса, на которую накладывается тонкая структура оптического пучка. Это позволяет анализировать коммутационные потери по значениям числовой апертуры волноводов. Расстояние $\Delta z$ между торцами полимеркварцевых волокон и апертурный угол $\theta_{1}$ определяются радиусом а волновода:

$$
\Delta z=a / \sin \theta_{1} .
$$

Из геометрических соображений следует, что для меридиональных лучей минимальные потери возможны при соотношении

$$
\theta_{1} \leqslant \theta_{2} / 3
$$

Косое падение лучей из волновода $5^{\prime \prime}$ (рис. 2, $a$ ) приводит к возбуждению немеридиональных направляющих мод волновода $1^{\prime \prime}$, локализованных в цилиндрической области в интервале радиусов $r$

$$
r_{t}<r<a
$$

где $r_{t}$ - радиус внутренней цилиндрической области, свободной от лучей [10]. Окружность числовой апертуры NA по углу при приеме

Письма в ЖТФ, 2018, том 44, вып. 14 
$a$

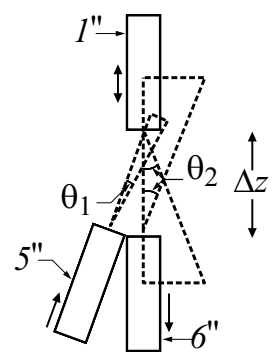

$b$

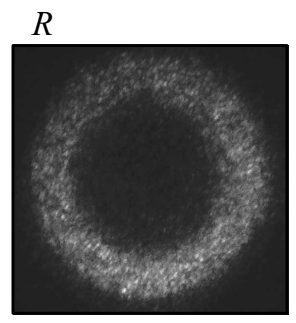

Pис. 2. Геометрия апертурных углов волноводов $(a)$ и интерференционная картина излучения торца оптического многомодового кварц-полимерного волокна в дальней зоне при возбуждении диодным лазером с $\lambda=650 \mathrm{~nm}(b)$.

меридиональных лучей преобразуется в эллипс с переменным эксцентриситетом при приеме немеридиональных лучей:

$$
\mathrm{NA}=\sin \theta_{0 c} /\left[1-(r / a)^{2} \sin \varphi\right],
$$

где $\theta_{0 c}-$ критический угол при возбуждении меридиональных лучей, $\varphi$ - азимутальный угол падения луча. Из (4) следует, что в предложенной схеме создание свободной от аксиальных мод центральной области волновода эквивалентно выполнению функции заграждающего фильтра. Это позволяет исключить медленные вариации спекловой структуры освещения объекта, возникающие вследствие температурных изменений и деформаций оптических волноводов. На схеме (рис. 2,a) представлены соотношения апертурных углов $\theta_{1}, \theta_{2}$ для передающего лазерное излучение волновода $5^{\prime \prime}$, принимающего флуоресцентный отклик волновода $6^{\prime \prime}$ и волновода зонда $1^{\prime \prime}$. На рис. $2, b$ представлены типичные изображения спекловой структуры излучения волновода при возбуждении аксиальных мод $(L)$ и циркулярных мод при косом падении пучка $(R)$.

Выбор числовой апертуры волокон влияет, в частности, на расстояние между сопряженными волокнами зонда и спектрометра. Очевидно, что минимальное расстояние между этими волокнами и соответственно максимальный коэффициент ввода мощности флуоресцентного излучения в спектрометр реализуются при максимальной числовой апертуре 
волокон. Увеличение регистрируемой мощности сигнала флуоресценции является более предпочтительным по сравнению с потерями при использовании избыточной мощности сигнала возбуждения. Этим определяется выбор одинаковой числовой апертуры для всех волокон, так как в соответствии с (1) при таком выборе можно уменьшить $\Delta z$.

При создании анализатора для ФСА биологических сред в ультрафиолетовом диапазоне нами были применены разные по спектрам пропускания кварц-полимерные волокна SPCH200-0.39NA $(210-1200 \mathrm{~nm})$ для работы волноводов в ультрафиолетовом диапазоне спектра. Коэффициент передачи мощности из волновода $5^{\prime \prime}$ в волновод $I^{\prime \prime}$ составил 0.3 на длине волны $650 \mathrm{~nm}$. Волновод $6^{\prime \prime}$, принимающий флуоресцентное излучение через волновод $l^{\prime \prime}$, в данном случае выполняет функцию заграждающего фильтра, что обусловило необходимость применения волокна FT200EMT-0.39NA (400-2200 nm). При этом получен коэффициент передачи мощности из волновода $1^{\prime \prime}$ в волновод $6^{\prime \prime}$ на длине волны $650 \mathrm{~nm}$, равный 0.6 .

Предложенная система неразрушающего ФСА была апробирована в задаче лабораторных зондовых исследований элементов зерновых смесей (ЭЗС) с целью выявления объектов, зараженных грибковыми заболеваниями (на примере арахиса). Такие ЭЗС подвержены заражению плесневыми грибами Aspergillus flavus и являются источником отравления человека афлатоксином $\mathrm{B}_{1}$. В экспериментах излучение сопряженного с волокном диодного лазера $(405 \mathrm{~nm})$ проходило через полосовой светофильтр FB405-10 и пассивным оптоволоконным коммутатором направлялось в оптоволоконный зонд. По этому зонду флуоресцентное излучение вместе с отраженным лазерным излучением возвращалось назад, фильтровалось на выходе коммутатора заграждающим фильтром NF405-13 и поступало на вход оптоволоконного спектрометра USB4000. Существенно, что оптоволоконный зонд позволил выполнить безопасное зондовое картирование поверхности ЭЗС, размещенных в защищенной среде (ламинарный шкаф) в режиме удаленного доступа. Другие типы волоконно-оптических зондов [4,5], решающих аналогичную задачу, могут быть использованы как физические волокна, но не как элементы невзаимного коммутатора малоапертурных оптических пучков.

Исследования спектров флуоресценции показали, что у зараженных грибами Aspergillus flavus бобов арахиса есть участки, флуоресценция которых не отличается от полученной для контрольных (незараженных) бобов. Поэтому далее оценивались участки флуоресценции

Письма в ЖТФ, 2018, том 44, вып. 14 


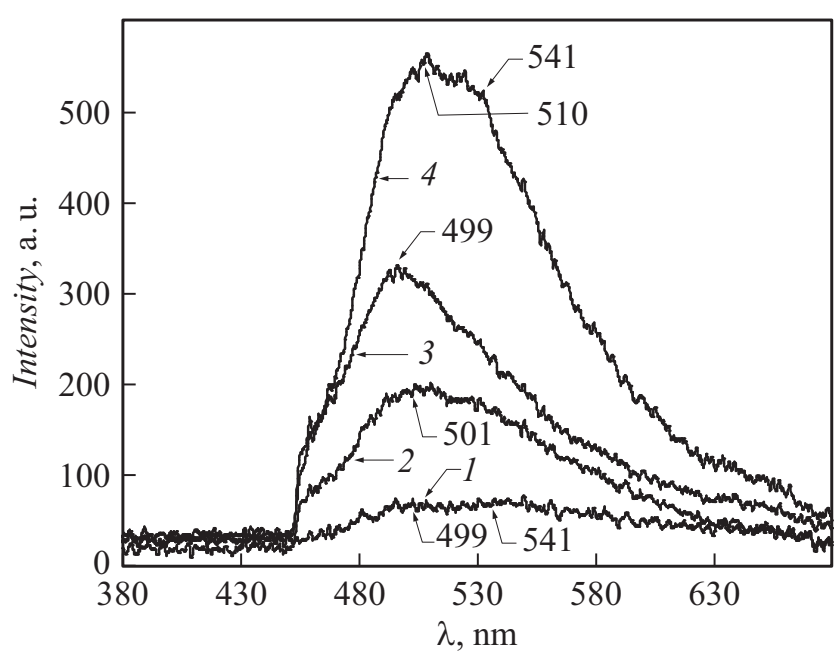

Рис. 3. Спектры флуоресценции бобов арахиса с колонией Aspergillus flavus, содержащей афлатоксин $\mathrm{B}_{1}$ : флуоресценция неповрежденных ЭЗС $(1)$ и поврежденных плесневыми грибами ЭЗС на 4 (2), 12 (3) и 24 сутки (4) развития колонии.

поверхности, интенсивность которых наиболее высока, что позволило оценивать динамику флуоресценции объектов исследования в различных временнб́х интервалах развития колонии. Типичные результаты экспериментов представлены на рис. 3. Из них следует, что интенсивность флуоресценции увеличивается с ростом колонии плесневых грибов. Полученные результаты позволили установить связь накопления биомассы колонии Aspergillus flavus с интенсивностью и формой спектра флуоресценции и свидетельствуют о перспективности применения разработанных средств ФСА для диагностики биологических сред и объектов.

Результаты работы получены в рамках выполнения государственного задания Министерства образования и науки РФ по проекту № 8.3844.2017/4.6 „Разработка средств экспресс-анализа и классификации элементов неоднородного потока зерновых смесей с патологиями на основе интеграции методов спектрального анализа и машинного обучения“. 


\section{Список литературы}

[1] Куликов К.Г. // ЖТФ. 2014. Т. 84. В. 4. С. 109-119.

[2] Куликов К.Г. // ЖТФ. 2014. Т. 84. В. 5. С. 154-158.

[3] Тучин В.В. Лазеры и волоконная оптика в биомедицинских исследованиях. М.: Физматлит, 2010. 478 c.

[4] Heckenberger $H$. Device for the recognition of caries, plaque or bacterial infection of teeth. Patent US6053731. 25.04.2000.

[5] Кульчин Ю.Н., Вознесенский С.С., Гамаюнов Е.Л., Коротенко А.А., Попик А.Ю., Майор А.Ю. // Оптика атмосферы и океана. 2013. Т. 26. В. 1. C. $40-45$.

[6] Hack $A$. Device for identifying caries, plaque, bacterial infection, concretions, tartar and other fluorescent substances on teeth. Patent US6561802. 13.05.2003.

[7] Трибонов А.С., Урих К.И. // Письма в ЖТФ. 1994. Т. 20. В. 16. С. 55-58.

[8] Сарычева И.Н., Янушевич О.О., Шульгин В.А., Минаков Д.А., Кашкаров В.М. Оптоволоконное устройство для регистрации флуоресценции. Патент № 2464549. Опубл.: 20.10.2012.

[9] Сарычева И.Н., Янушевич О.О., Шульгин В.А. Оптоволоконный коммутатор лазерного спектроанализатора. Патент № 2632993. Опубл.: 11.10.2017.

[10] Unger H.G. Planar optical waveguides and fibres. Oxford University Press, 1977. $770 \mathrm{p}$. 